\title{
DEVELOPMENT AND STANDARDIZATION OF HIGH FREQUENCY WORD LISTS IN NEPALI
}

Contributions: A Study design/planning B Data collection/entry C Data analysis/statistics C Data analysis/statistics D Data interpretation E Preparation of manuscrip F Literature analysis/search $\mathrm{G}$ Funds collection

\section{Anup Ghimire ${ }^{1 A B C D E F}$, Prashanth Prabhu ${ }^{1 A B C D E F}$, Bebek Bhattarai'2ABDEF, Anuj Kumar Neupane ${ }^{3 A C E F}$}

${ }^{1}$ Department of Audiology, All India Institute of Speech and Hearing, Manasagangothri, Mysore, Karnataka, India

${ }^{2}$ Department of ENT, Tribhubhan University Teaching Hospital, Kathmandu, Nepal

${ }^{3}$ Department of Audiology and Speech Therapy, C.U. Shah Medical College and Hospital, Surendranagar, Gujarat, India

Corresponding Author: Anuj Kumar Neupane, Department of Audiology and Speech Therapy, C.U. Shah Medical College and Hospital, Surendranagar 363001, Gujarat, India; email: anujkneupane@gmail.com, tel.+918792482481

\begin{abstract}
Background: Speech is a stimulus with high redundancy because the information in it is conveyed in several ways simultaneously. Because of redundancy, a regular speech identification test is largely insensitive to identifying high frequency hearing loss in a subject. The present study aimed to develop and standardise a word list in the Nepali language in which the selected words have elevated high frequency content.

Material and methods: The study was conducted in three phases. The first stage was to develop a high frequency word list, which was completed by gathering familiar bisyllabic words, recording them, and then selecting words dominant in high frequencies. In stage 2 , the developed word list was administered to 100 individuals with normal hearing. In stage 3 , the final lists were administered to 10 individuals with simulated high frequency hearing loss in order to determine the usefulness of the list. Finally, 7 psychometrically equivalent word lists with 20 words per list were developed.
\end{abstract}

Results: Normal hearing individuals showed Speech Identification Scores of more than $95 \%$ whereas in the case of the simulated high frequency loss group, significantly poorer speech identification scores were obtained.

Conclusions: This present study standardised high frequency word lists in Nepali and all the lists were validated in subjects with simulated high frequency hearing loss. Hence, this can be used as a standard high frequency word list in the Nepali population.

Key words: speech audiometry $\bullet$ word lists $\bullet$ Nepali $\bullet$ speech identification scores

\section{DESARROLLO Y NORMALIZACIÓN DE PALABRAS CON ALTA FRECUENCIA EN NEPALÍ}

\section{Resumen}

Introducción: el habla es un estímulo con alta redundancia porque la información contenida en ella se transfiere de varias formas al mismo tiempo. Debido a la redundancia, la sensibilidad de la prueba de identificación del habla tradicional es demasiado baja para identificar la pérdida de audición en el paciente para frecuencias altas. Este estudio tuvo como objetivo desarrollar y estandarizar una lista de palabras en nepalí en la que las palabras elegidas incluyeran un elevado contenido de sonidos de alta frecuencia.

Material y métodos: El estudio se realizó en tres fases. La primera etapa consistió en desarrollar una lista de palabras de alta frecuencia que consistió en reunir palabras conocidas de dos silabas, guardarlas y luego seleccionar las palabras en que prevalecen los sonidos de alta frecuencia. En la segunda etapa, se usó la lista de palabras desarrollada con 100 personas con audición normal. En la tercera etapa, se realizaron pruebas con las listas finales en 10 personas con una pérdida auditiva simulada para el rango de alta frecuencia y así determinar la idoneidad de la lista. Finalmente, se desarrollaron 7 listas psicométricas equivalentes de 20 palabras cada una.

Resultados: los oyentes obtuvieron puntuaciones de identificación del habla (Speech Identification Scores) de más del 95\%, mientras que, en el caso del grupo con pérdida de audición simulada para el rango de alta frecuencia, se obtuvieron resultados de identificación del habla mucho peores.

Conclusiones: como resultado de este estudio, las listas de palabras de alta frecuencia en nepalí se han estandarizado. Todas las listas se validaron como resultado de un estudio realizado en personas con pérdida auditiva simulada en el rango de alta frecuencia. Por lo tanto, pueden ser usadas como listas estándar de palabras de alta frecuencia en la población nepalí.

Palabras clave: audiometría del habla • listas de palabras • nepalí • resultados de identificación del habla 


\title{
РАЗРАБОТКА И СТАНДАРТИЗАЦИЯ СПИСКОВ ВЫСОКОЧАСТОТНЫХ СЛОВ В ЯЗЫКЕ НЕПАЛИ
}

\begin{abstract}
Аннотация
Введение: Речь является стимулом с высоким уровнем редундантности, потому что информация передается в ней несколькими способами одновременно. Из-за избыточности стандартный тест идентификации речи не имеет достаточного уровня чувствительности для выявления высокочастотной потери слуха у пациента. Настоящее исследование направлено на разработку и стандартизацию списка слов на непальском языке, в котором выбранные слова имеют повышенное содержание зву-
\end{abstract} ков на высоких частотах.

Материалы и методы: Исследование проводилось в три этапа. Первым этапом была разработка высокочастотного списка слов. Сначала были отобраны двусложные слова, записаны, а затем выбраны слова с доминирующими звуками на высоких частотах. На втором этапе был разработан список слов, который протестировали 100 человек с нормальным слухом. На 3 этапе окончательные списки были представлены 10 пациентам, у которых была симуляция потери слуха на высоких частотах для того, чтобы определить эффективность списка. Наконец, было разработано 7 психометрически эквивалентных списков слов, по 20 слов в каждом списке.

Результаты: У лиц с нормальным слухом показатели идентификации речи (Speech Identification Scores) превышали 95\%, тогда как в случае группы с симуляцией высокочастотной потери слуха были получены значительно более низкие показатели идентификации речи.

Выводы: В результате данного исследования удалось создать стандартизированные высокочастотные списки слов в непальском языке. Все списки были протестированы пациентами с симуляцией высокочастотной потери слуха. Следовательно, они могут быть использованы в качестве стандартного высокочастотного списка слов в непальской популяции.

Ключевые слова: речевая аудиометрия • списки слов • непальский язык • показатели идентификации речи

\section{OPRACOWANIE I STANDARYZACJA LIST SŁÓW O WYSOKIEJ CZĘSTOTLIWOŚCI W NAPALI}

\section{Streszczenie}

Wstęp: Mowa jest bodźcem o dużej redundancji, ponieważ informacje w nim zawarte są przenoszone na kilka sposobów jednocześnie. Ze względu na nadmiarowość czułość tradycyjnego testu identyfikacji mowy jest zbyt niska, aby zidentyfikować u pacjenta utratę słuchu w zakresie wysokich częstotliwości. Niniejsze badanie miało na celu opracowanie i standaryzację listy słów w języku nepalskim, w którym wybrane słowa zawierają podwyższony udział dźwięków wysokiej częstotliwości.

Materiał i metody: Badanie przeprowadzono w trzech fazach. Pierwszym etapem było opracowanie listy słów o wysokiej częstotliwości, która polegała na zebraniu znanych dwusylabowych słów, zapisanie ich, a następnie wybranie słów, w których przeważają dźwięki o wysokich częstotliwościach. W drugim etapie opracowaną listę słów zastosowano u 100 osób z prawidłowym słuchem. Natomiast w trzecim etapie testy z ostatecznymi listami zostały przeprowadzone u 10 osób z symulowaną utratą słuchu w zakresie wysokich częstotliwości w celu określenia przydatności listy. Ostatecznie opracowano 7 równoważnych psychometrycznie list zawierających 20 słów.

Wyniki: Osoby słyszące prawidłowo uzyskały wyniki identyfikacji mowy (Speech Identification Scores) na poziomie ponad 95\%, podczas gdy w grupie z symulowaną utratą słuchu w zakresie wysokich częstotliwości uzyskano znacznie gorsze wyniki identyfikacji mowy.

Wnioski: Na podstawie wyników niniejszego badania wystandaryzowano listy słów o wysokiej częstotliwości w języku nepalskim. Wszystkie listy zostały zwalidowane na podstawie badania przeprowadzonego u osób z symulowaną utratą słuchu w zakresie wysokich częstotliwości. Dlatego też mogą być one stosowane jako standardowe listy słów o wysokich częstotliwościach w populacji nepalskiej.

Słowa kluczowe: audiometria mowy • listy słów $\bullet$ nepalski • wyniki identyfikacji mowy

\section{Abbreviations}

ANSI - American National Standards Institute

PTA - pure tone average

FFT - fast fourier transform

LTASS - long term average speech spectrum

SL - sensation level

SIS - speech identification score

SRT - speech recognition threshold

\section{Background}

Hearing loss is generally assessed and quantified using pure tone audiometry, which is the gold standard test. However, pure tone audiometry is a test of sensitivity and cannot assess an individual's ability to understand speech. Speech sounds carry complex and dynamic acoustic information that changes over time in spectrum and level [1]. Evaluation of an individual's ability to understand conversational speech is a difficult task and mostly tools such as the speech recognition threshold test and the speech identification scores test are used [2]. Different stimuli can be used in speech audiometry, such as nonsense syllables, consonants, words, digits, and sentences. Most often, the speech identification test consists of phonetically balanced word lists in a specific language and is standardised for a flat hearing loss configuration. This might result in higher speech identification scores (SISs) in an individual with a different type of hearing loss configuration such as a high frequency sloping hearing loss in which there is no issue for speech perception with spectral information below $2 \mathrm{kHz}$. However, diminished speech perception scores can be seen in the presence of background noise, since it disrupts information at low frequencies which 
cue the perception [3]. Moreover, high frequency hearing loss might especially lead to a difficulty in perceiving high frequency unvoiced consonants such as $/ \mathrm{t} /, / \mathrm{k} /, / \mathrm{f} /$, /sh/, and /s/ [4].

A standard speech identification test can give a reasonably accurate prediction of the best hearing threshold levels in the mid frequency region of the auditory range. Speech identification assessments should measure an individual's ability to understand speech and provide an estimate of the degree of communication disability caused by hearing loss [5]. However, many individuals with high frequency sloping hearing loss often do not show reduced speech identification performance when assessed with conventional speech identification tests.

Therefore, to answer this need, a high frequency speech identification test was developed which included consonants having high frequency spectral energy; the test is useful in detecting communication difficulties in individuals with high frequency sloping hearing loss [3]. To perceive speech in the presence of background noise, information at frequencies above $2 \mathrm{kHz}$ is significant [6]. Kuk et al. [7], when analysing voiceless consonants from samples of adults, reported fricatives to have the highest spectral peak compared to other phonemes. Though other voiceless phonemes have less marked peaks in their spectra, they have important spectral energy located at higher frequencies with rising spectral slope above $1.6 \mathrm{kHz}$ [7]. Maroonroge and Diefendorf [8] performed the NU 6 test and Pascoe's High-Frequency Test in two groups of individuals. Group I comprised normal hearing individuals with high frequency sloping hearing loss above $2 \mathrm{kHz}$ and group II included individuals with normal hearing sensitivity across all octave frequencies. Individuals in group I were found to have near-normal response for the NU 6 test and significantly poorer scores for Pascoe's High-Frequency Test, showing that the latter test had higher sensitivity in determining communication difficulties in individuals with high frequency hearing loss compared to the former. A similar study by Sher et al. [9] also reported the importance of auditory cues above $2 \mathrm{kHz}$ for discrimination of words that include high frequency phonemes in isolation.

High frequency hearing loss is a common audiogram configuration seen in individuals with cochlear hearing loss [3,10-13]. There are high frequency speech identification tests developed in different South Asian languages such as Hindi [14], Kannada [15], Indian English [16], Tamil [17], Telugu [18], and Indian English children [19]. Moreover, speech perception in an individual is influenced by the mother tongue, and hence comparatively better scores are obtained if the test is performed in the mother tongue $[20,21]$.

The official language of Nepal is Nepali which is spoken and understood by most Nepalese, as well as a few states in India such as Darjeeling and Sikkim. Due to a lack of standard test material with high frequency word lists, there are no assessment tools to understand the communication difficulty of Nepali-speaking individuals with high frequency hearing loss. According to epidemiological data, $16.6 \%$ of the population in Nepal have hearing impairment of various degrees and configuration [22]. Although there are a few tests developed in Nepali such as the Screening Picture Identification Test [23], and some low-frequency Nepali word lists have been developed [24], high frequency word lists are not yet available.

Therefore, to measure the speech perception ability of individuals with high frequency hearing loss and to be able to plan appropriate management options such as amplification devices or other communication aids, it is necessary to use a test that is sensitive to the problem. It is likely that if a regular phonetically balanced word list is used in such individuals, the aided and the unaided scores might not be significantly different. Thus, it would then be difficult to assess the benefit that one might get from a hearing aid. However, if a high frequency word list is used in individuals with sloping hearing loss, we can expect a significant difference in aided and unaided performance. Thus, it is important to develop a high frequency word list which can help in rehabilitation of Nepali speaking individuals with high frequency hearing loss. Hence, the present study aimed:

- To develop high frequency word lists in Nepali to evaluate SISs in individuals with predominantly high frequency hearing loss.

- To establish normative data for the developed material in normal hearing adults who are native speakers of Nepali.

- To administer the test on a group of individuals with a sloping type of audiogram (or simulated high frequency hearing loss) to check its utility.

\section{Material and methods}

Routine audiological evaluation was carried out on all participants in an air-conditioned, well lit, and acoustically treated double-walled room as per ANSI S3.1 (1999). A calibrated dual channel diagnostic audiometer GSI-61 was used to carry out pure tone and speech audiometry. The developed speech materials were routed through MATLAB R2000b software to the auxiliary input of the calibrated audiometer to test SISs at $40 \mathrm{~dB}$ SL (ref: PTA). SISs were obtained using four developed word lists for both right and left ears on 100 native Nepali speaking individuals with normal hearing. The participants were asked to follow instructions and respond by verbal repetition. The objectives and procedures of the study were explained to the participants before evaluation and informed consent was obtained. All procedures were in accordance with the 1964 Helsinki declaration and its later amendments or comparable ethical standards.

The study was carried out in three stages:

Stage 1: The development of the high frequency word lists.

Stage 2: Administration of word lists on native Nepali speaking individuals with normal hearing.

Stage 3: Determining the usefulness of the test material with simulated high frequency hearing loss. 

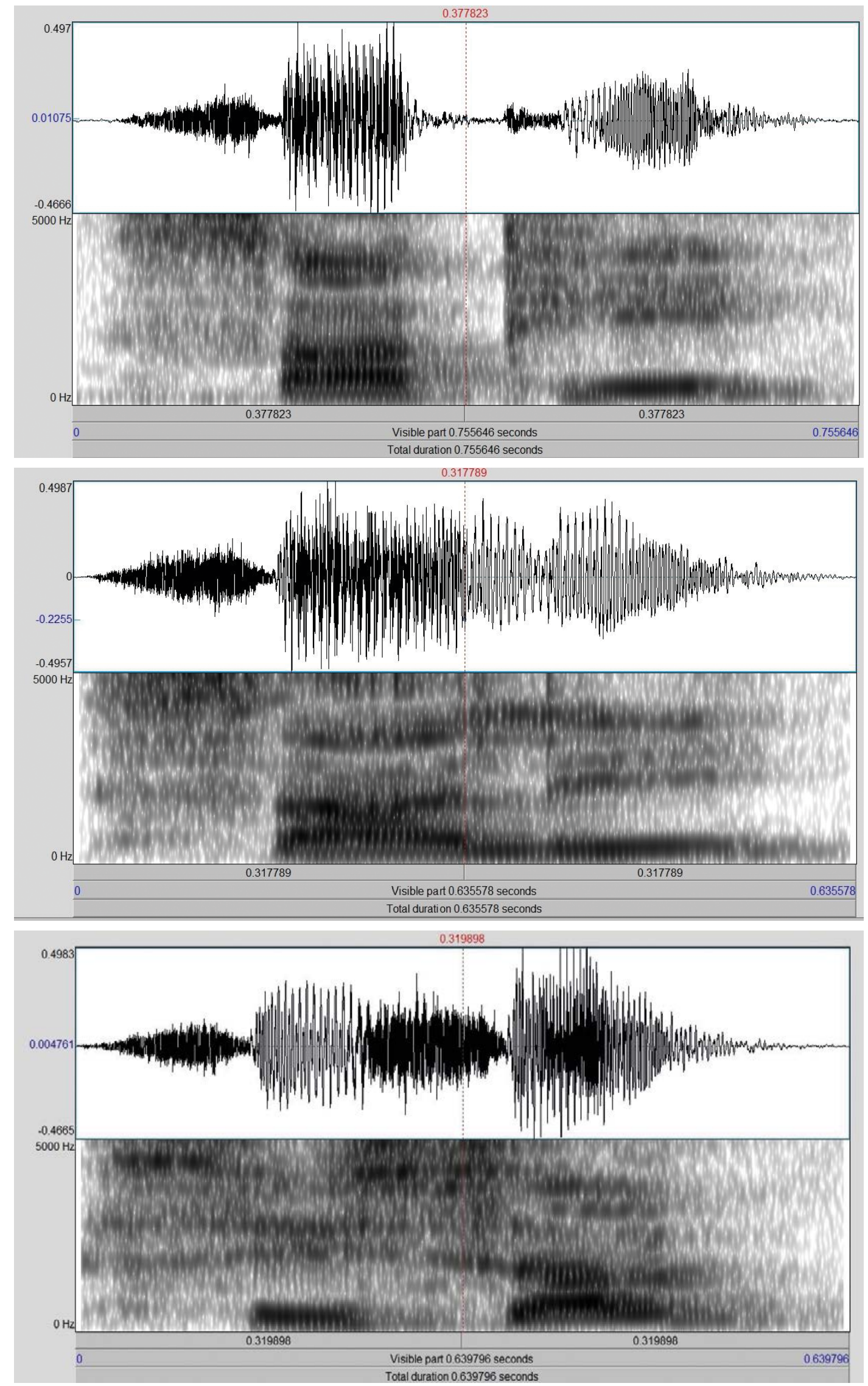

Figure 1. Spectrogram of Nepali high frequency word /saӨi/ shown in PRAAT software (a); /sali/ (b); and /sifa/ (c). 


\section{Stage 1: Development of the high frequency word} lists

\section{Selection of the words and familiarity rating}

Exactly 700 bisyllabic Nepali words were collected from different sources (common newspapers, magazines, books). High frequency words were selected based on the energy of phonemes they contained, so that they had to have more than $60 \%$ high frequency phonemes: vowel /i/; semivowels /j/, /r/, /l/; stops /t/, /th/, /k/; fricatives /s/, /sh/, /f/; and affricatives /ch/. Only words which could be visualised were included (abstract words were not included). Words with multiple meaning were also excluded. Out of the 700 bisyllabic words, 200 were found to have predominant high frequency energy and were selected for the final wordlist. These words were checked for the presence of script errors and as being correctly categorised as bisyllabic words. The corrected word list was given to 10 literate adult native Nepali speakers to rate the words on a 5-point familiarity rating scale. The words rated familiar, more familiar, or most familiar by $70 \%$ of the participants were considered and the rest of the words were excluded.

\section{Recording of words and selection of best recorded words}

The selected words were recorded in a sound treated room using an Olympus WS-852 digital voice recorder with microphone placed 6 inches away from the speaker to reduce plosive and breathing noise (proximity effects). Each word was recorded five times in a clear and monotonous voice. Out of the five recordings, the first and last recordings were removed (to eliminate artifacts induced by initiation and ending of the recording) and only the middle three were subjectively and objectively analysed for the best recorded words. Objective analysis was done using PRAAT software. Sample spectrograms of three of the words selected for the word lists are shown in Figure 1. Subjectively, words were analysed and rated by an experienced audiologist for clarity of utterance, presence of any intonation patterns, and audible background noise. Out of the three repetitions of each word, the best rated recordings, free of background noise, clear, and monotonous, were retained. Also, the word with visible pitch in objective analysis using PRAAT was selected for the final wordlist. The final wordlist was then normalised for intensity.

\section{Separating words with dominant high frequency energy}

The verification of words was done using MATLAB, and fast fourier transforms (FFTs) were done. The amplitudes below and above $1.2 \mathrm{kHz}$ were obtained for all words individually, and the ratios calculated. Further, based on these amplitude ratios, $k$-means clustering was applied to all the words. With $k$-means clustering, the total data was divided into a number of clusters, each with a nearest mean. Those words with dominant high frequency energy compared to the rest of the words were selected. In this way, a group of words with energy concentrated on the maximum phoneme and with high frequencies was selected.
Further, using MATLAB the long term average speech spectrum (LTASS) was obtained for the clusters of high frequency words. This was done to further verify the correct categorisation of words as high frequency dominant. Thus, the word list was further shortlisted making sure there was a predominance of high frequency energy.

\section{Generating word lists of equal difficulty}

All the high frequency range words were then presented 25 times to adult native Nepali speakers with normal hearing ( 5 participants for each SL at 5 different sensation levels (ref: PTA)). Sensation levels (SLs) of $+0,+4,+8$, +12 , and $+16 \mathrm{~dB}$ were considered. The signal was routed through a personal computer to the calibrated audiometer and presented through Sennheiser HDA-200 headphones. All the high frequency words were presented at one sensation level (SL) for each participant, and at each SL data was collected from 5 participants. SISs were calculated using the following formula:

$$
\text { SIS }=\frac{\text { Obtained number } \text { of responses }}{\text { Total number of responses }}{ }^{\star} 100
$$

The SISs obtained from the participants at each SL were averaged and tabulated. Based on the average scores at all SLs, psychometric functions were derived for all the words using MATLAB. Mean sensation level at which an SIS of $50 \%$ occurred, and mean slope of the psychometric function, was obtained. Words falling within \pm 1.5 standard deviations of the overall mean and slope were accepted. These words were used to make the final word lists of 20 words each. For constructing an equalised list, firstly 20 words were randomly selected from the available word pool. For each list, mean SL where $50 \%$ scores occurred and mean slope were found. The mean SL and slope were compared with the overall mean SL and slope of the high frequency word pool obtained initially. If the mean value was within \pm 1.5 standard deviations, then the list considered was selected. If not, then another set of 20 words was randomly selected and the procedure was repeated. In this way, we attempted to develop at least 4 word lists with 20 words in each list.

\section{Stage 2: Administration of word lists on individ- uals with normal hearing}

SISs using the developed test material was obtained from 100 adult native speakers of Nepali. All the participants were literate with a minimum education of $10^{\text {th }}$ grade. Participants were 64 males and 36 females aged 16 to 35 years (mean 24.81, SD 3.95). All participants had normal hearing sensitivity ( $\leq 15 \mathrm{~dB}$ HL air conduction and bone conduction thresholds at octave frequencies), with no history of otological problem and normal middle ear functioning based on immittance findings.

\section{Results}

Tests of normality of the data was done with a ShapiroWilks test, which revealed the data was not normally distributed $(p<0.05)$. 


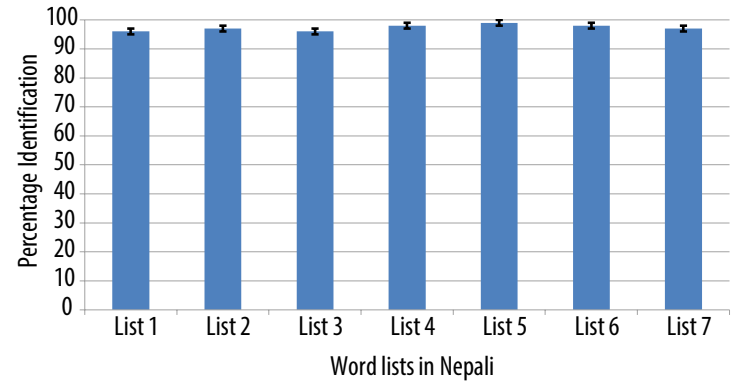

Figure 2. Mean and standard deviation of speech identification scores obtained for high frequency word lists in Nepali language for normal individuals at $40 \mathrm{dBSL}$

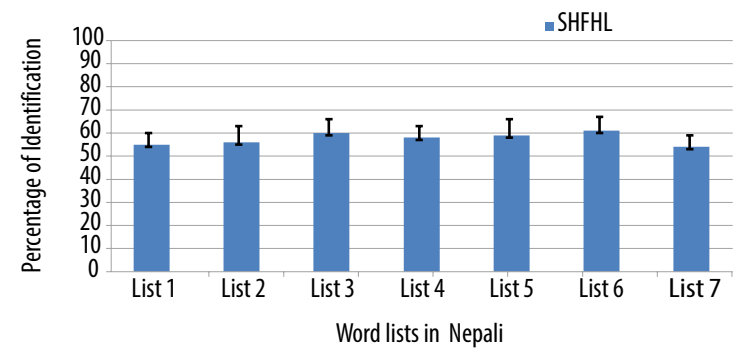

Figure 3. Mean and SD of speech identification scores obtained for high frequency word lists in Nepali for simulated high frequency hearing loss (SHFHL) individuals at $40 \mathrm{dBSL}$

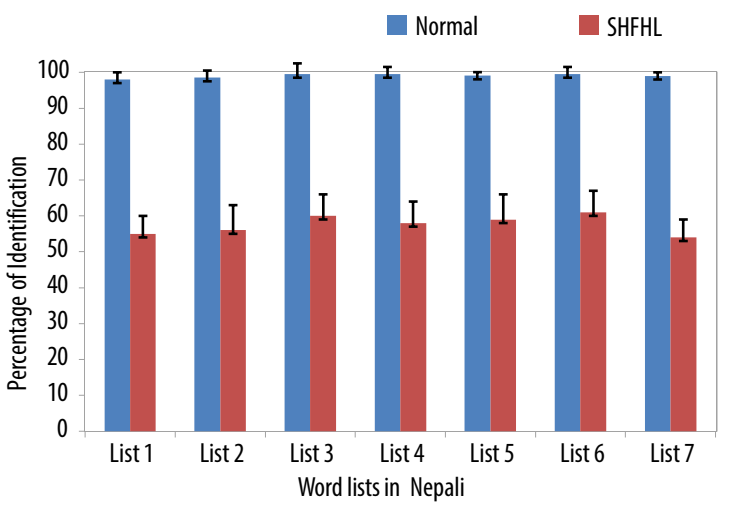

Figure 4. Mean and standard deviation of speech identification scores obtained for high frequency word-lists in Nepali language for normal and simulated high-frequency hearing loss (SHFHL) individuals at $40 \mathrm{dBSL}$

Hence, Friedman's test was performed to compare the SISs between the 7 lists in individuals with normal hearing, which revealed no significant difference across the 7 lists $(p>0.05)$. To determine the usefulness of the developed list, a Mann-Whitney U-test was performed to compare the SISs between individuals with normal hearing and individuals with simulated high frequency hearing loss. Results of the U-test revealed that the SISs were significantly reduced $(p<0.01)$ for individuals with simulated high frequency hearing loss compared to individuals with normal hearing.
The Friedman test was used to compare SISs obtained from the high frequency lists in individuals with simulated high frequency hearing loss. The results showed a significant difference between the lists. Hence, a Wilcoxon signed rank test was further administered to compare SISs between the 7 word lists, and this showed no significant difference $(p>0.05)$ in individuals with simulated high frequency cochlear hearing loss.

\section{Discussion}

Speech is made up of high redundancy stimuli with information conveyed in various ways simultaneously. A standard speech perception test can fairly accurately predict hearing thresholds at mid frequencies. However, a hearing loss affecting only a part of the frequency range may not be identified in a speech perception test. Hence, the regular speech identification test has low sensitivity in identifying that a person with high frequency sloping hearing loss has a problem. In this case, it is essential to use speech test material that contains only high frequency speech sounds [25].

There are no standard and valid published speech materials developed in Nepali to assess SISs and speech recognition thresholds (SRTs). The only developed test material is the Screening Picture Speech Identification Test for Nepali Speaking Children [22] which is useful in determining the communication difficulties of children with flat hearing loss. Thus, the present study provides a valuable tool to assess high frequency perception in Nepali speaking individuals.

High frequency word lists have been developed in several different South Asian languages [14-19]. The present study followed a similar methodology except that the words collected during the initial phase contained prominent high frequency phonemes. SISs obtained by simulated high frequency cochlear hearing loss individuals for Hindi, Kannada, English, Tamil, and Telugu high frequency word lists are similar to those in Nepali [14-19]. SISs of $100 \%$ for high frequency words in normal hearing individuals seen in the present study are in agreement with earlier studies $[15,16]$.

This indicates that the Nepali high frequency word lists would have similar high frequency content and sensitivity as those of the other languages. Additionally, in the present study words with only high frequency phonemes were selected and the word lists were objectively verified using FFT and LTASS. Across the 7 lists there was no significant difference between the normal hearing and the simulated hearing loss group, which suggests that the word lists have equal difficulty. This validated the efficacy of the high frequency word lists. However, the scores obtained for the high frequency word lists and from simulated high frequency sloping hearing loss individuals showed a significant difference. The reason for this difference might be due to the perception of all phonemes (high and mid) by normal hearing individuals, whereas in the simulated condition the lower scores are due to an inability to perceive high frequency information [25]. This confirms that the high frequency word list is an effective tool for the assessment of high frequency hearing sensitivity. 


\section{Conclusions}

The study aimed at developing high frequency word lists in Nepali. Seven word lists were developed which were equal in difficulty. We conclude that this high frequency Nepali word list is able to be used in routine speech identification testing, assessment of hearing aid benefits, and for research that requires multiple word lists.

\section{Conflict of interest statement}

None

\section{Funding}

This research did not receive any specific grant from funding agencies in the public, commercial, or not-forprofit sectors.

\section{References}

1. Niemeyer W. Speech audiometry with sentences. I. Principles and test material of the diagnosis of whole speech perception, $\mathrm{HNO}$, 1967; 15 (11): 335-43

2. Goldinger SD, Pisoni DB, Logan JS. On the nature of talker variability effects on recall of spoken word lists. J Exp Psychol Learn Mem Cogn, 1991;17(1):152.

3. Gardner HJ. Application of high frequency consonant discrimination word list in hearing aid evaluation. J Speech Hear Dis, 1971;36(3): 354-55.

4. Dubno JR, Dirks DD, Schaefer AB. Stop-consonant recognition for normal-hearing listeners and listeners with high-frequency hearing loss. II: Articulation index predictions. J Acoust Soc Am, 1989; 85(1): 355-64.

5. Waghmare P, Mohite J, Gore G. Development of Marathi speech recognition test (pediatric): a preliminary report. J Indian Speech Hear Assoc, 2011; 25(1): 59-64.

6. Kryter KD, Williams C, Green DM. Auditory acuity and the perception of speech. J Acoust Soc Am, 1962; 34(9A): 1217-23.

7. Kuk F, Keenan D, Korhonen P, Lau C. Efficacy of linear frequency transposition on consonant identification in quiet and in noise. J Am Acad Audiol, 2009; 20(8): 465-79.

8. Maroonroge S, Diefendorf AO. Comparing normal hearing and hearing-impaired subject's performance on the Northwestern Auditory test Number 6, California Consonant Test, and Pascoe's High-Frequency Word Test. Ear Hear, 1984; 5(6), 356-60.

9. Sher AE, Owens E. Consonant confusions associated with hearing loss above $2000 \mathrm{~Hz}$. J Speech Hear Res, 1974; 17(4): 669-81.

10. Pascoe DP. Frequency responses of hearing aids and their effects on the speech perception of hearing-impaired subjects. Ann Otol Rhinol Laryngol, 1975; 84(23 Suppl.): 3-40.

11. Jerger J, Jerger S. Diagnostic significance of PB word functions. Arch Otolaryngol, 1971; 93(6): 573-80.
12. Owens E, Schubert ED. Development of the California Consonant Test. J Speech Hear Res, 1977; 20(3): 463-74.

13. Lacroix PG, Harris JD, Randolph K. Multiplicative effects on sentence comprehension for combined acoustic distortions. ASHA; 1979.

14. Ramachandra P. High Frequency Speech Identification Test for Hindi. Unpublished Master's Dissertation. University of Bangalore, India; 2001.

15. Kavitha EM. High Frequency Kannada Speech Identification Test (HF-KST). University of Mysore; 2002.

16. Sudipta KB. High Frequency-English Speech Identification Test (HF-ESIT). University of Mysore; 2006.

17. Sinthiya KM. High Frequency Speech Identification Test in Tamil. University of Mysore; 2009.

18. Ratnakar YV. High Frequency Speech Identification Test in Telugu. University of Mysore; 2010.

19. Nakhawa SC. Development and evaluation of High Frequency Word Identification Test for children in Indian-English (HF-WITCIE). University of Mysore; 2017.

20. De NS. Hindi PB list for speech audiometry and discrimination test. Ind J Otolaryngol, 1973; 25(2): 64-75.

21. Singh S, Black JW. Study on 26 intervocalic consonants as spoken and recognised by four language groups. J Acoust Soc Am, 1966; 39: 372-87.

22. Little P, Bridges A, Guragain R, Friedman D, Prasad R, Weir N. Hearing impairment and ear pathology in Nepal. J Laryngol Otol, 1993; 107(5): 395-400.

23. Lal KS. A Screening Picture Speech Identification Test for Nepali speaking children. Nepal J ENT Head Neck Surg, 2012; 3(2): 15.

24. Ghimire A. Development of Low Frequency word lists in Nepali Language. University of Mysore; 2019.

25. Martin FN, Armstrong TW, Champlin CA. A survey of audiological practices in the United States. Am J Audiol, 1994; 3(2), 20-26. 